Gorjana Vujović ${ }^{1}$

Đorđe Petronić ${ }^{2}$

Katedra za psihologiju

Filozofski fakultet

Univerzitet u Istočnom Sarajevu

Istočno Sarajevo, Republika Srpska
UDK 159.923.072:316.62

Originalni naučni rad

https://doi.org/10.46630/gpsi.17.2020.02

\title{
OTPORNOST KAO PREDIKTOR DRUŠTVENO NEPRIHVATLJIVOG PONAŠANJA
}

\begin{abstract}
Apstrakt
Problem istraživanja je operacionalizovan kao ispitivanje mogućnosti predviđanja društveno neprihvatljivog ponašanja na osnovu otpornosti. U tom kontekstu ispitivano je samoprijavljeno društveno neprihvatljivo ponašanje, dok je otpornost analizirana kroz dva aspekta. Prvi je Ego-otpornost koja je definisana kao crta ličnosti i odnosi se na prilagodljivost prilikom inhibiranja ili ispoljavanja emocija (impulsa) u zavisnosti od zahtijeva sredine u kojoj se osoba nalazi. Drugi aspekt je otpornost definisana kroz intrapersonalne i interpersonalne kapacitete osobe koji utiču na adaptaciju i toleranciju na stres i negativne životne događaje. Istraživanje je realizovano na prigodnom uzorku od 384 ispitanika iz populacije učenika završnih razreda srednjih škola, sa područja Republike Srpske (Bosna i Hercegovina). Primjenjena je hijerarhijska regresiona analiza. Od mjernih instrumenata korišteni su: Skala otpornosti za odrasle (RSA - Resilience Scale for Adults); Skala Ego-otpornosti; iz Upitnika Velikih pet+2 korištene su skale za ispitivanje dimenzija Agresivnost i Savjesnosti i Skala socijalno neprihvatljivog ponašanja. Rezultati su pokazali da se nakon kontrolisanja varijanse Savjesnosti i Agresivnosti u hijerarhijskoj regresionoj analizi otpornost pokazala kao statistički značajan prediktor društveno neprihvatljivog ponašanja $\left(R=.40, R^{2}=.160\right.$, $F(4,318)=15.09, p=.000)$. Kada su pojedinačni prediktori u pitanju najdominantnije su dimenzije inventara Velikih pet +2 , Savjesnost $(\beta=-.24, p=000)$ i Agresivnost $(\beta$ $=.19, p=.000)$, nakon čega slijedi otpornost $(\mathrm{RSA} ; \beta=-.16, p=.012)$. Ego-otpornost nije statistički značajan prediktor društveno neprihvatljivog ponašanja $(\beta=.06, p$ $=.342$ ). Dobijeni rezultati su značajni u kontekstu razumijevanja uzroka društveno neprihvatljivog ponašanja, a time i preventivnog djelovanja.
\end{abstract}

Ključnje riječi: otpornost, Ego-otpornost, društveno neprihvatljivo ponašanje

\section{Uvod}

Otpornost (engl. resilience) jeste pojam koji se sve češće upotrebljava u kontekstu mentalnog zdravlja. Uprkos velikom broju istraživanja koja su za cilj imala ispitivanje otpornosti, te različitih faktora zaštite i rizika koji se sa njim dovode $\mathrm{u}$ vezu, izostala je jedinstvena definicija pojma. Razlog tome je upotreba

\footnotetext{
${ }^{1}$ gorjana.vujovic@ffuis.edu.ba

${ }^{2}$ djordje.petronic@ffuis.edu.ba
} 
otpornosti u različitim kontekstima. Naime, definicija se mijenja u zavisnosti od toga da li se otpornost posmatra kao proces, osobina ličnosti, rezultat razvoja ili sve to zajedno. Ono što je zajedničko svim definicijama jeste centralno pitanje: Kako neke osobe uprkos doživljenim traumama, izloženosti jakim i kontinuiranim stresorima uspijevaju u tome da se neometano razvijaju i očuvaju mentalno zdravlje bez posljedica? Odgovor na ovo pitanje jeste upravo u konstruktu otpornosti, koji je u cjelini zaslužan za očuvanje mentalnog zdravlja pojedinca.

Otpornost u doslovnom prevodu sa engleskog jezika znači "savitljiv, elastičan" i odnosi se na elastičnost u kontekstu sposobnosti vraćanja u prvobitno stanje, bez oštećenja (Vujović i Petronić, 2019). U najopštijem smislu, otpornost predstavlja pozitivnu adaptaciju ili sposobnost održavanja mentalnog zdravlja uprkos doživljenim poteškoćama (Herman, Stewart, Diaz-Granados, Berger, Jackson, \& Yuen, 2011). Jedna od definicija otpornosti jeste da je to kapacitet koji osoba ima u kontekstu podnošenja određene količine stresa bez fundamentalnih izmjena u sposobnosti za izvršavanje razvojnih zadataka (Zatura, Hall, \& Murray, 2008). Veća sposobnost osobe da ostane na adekvatnom razvojnom putu znači ujedno i veću otpornost. Otpornost je moguće definisati kao dostignuće pozitivnih razvojnih ishoda i izbjegavanje neprilagođenih ishoda pod štetnim uslovima (Goldstein \& Brooks, 2013).

U ovom radu otpornost je analizirana kao crta ličnosti (Ego-otpornost), te kao kapacitet koji utiče na adaptaciju i toleranciju na stres i negativne životne događaje.

Otpornost posmatrana kao crta ličnosti je definisana kao Ego-otpornost (Block \& Kremen, 1996). Prilikom definisanja Ego-otpornosti polazi se od objašnjenja konstrukta Ego-kontrola. Ego-kontrola je meta-dimenzija impulsivnosti u kontekstu ispoljavanja/inhibicije impulsa, dok je Ego-otpornost karakteristika ličnosti koja se odnosi na prilagodljivost inhibiranja/izražavanja emocionalnih reakcija u zavisnosti od zahtjeva sredine (Block, Block, \& Keyes, 1988).

Osobe koje su sklone pretjeranoj kontroli impulsa sputavaju impluse i reakcije u svim situacijama, čak i kada to nije potprebno. Imaju problem prilikom donošenja odluka i često izbjegavaju nagrade i lična zadovoljstva, čvrsto se drže svoje organizacije i u stanju su da kontinuirano obavljaju iste zadatke dugo vremena. $\mathrm{Na}$ drugom kraju su osobe koje su sklone pretjeranom ispoljavanju impulsa čak i kada to nije preporučljivo. Nisu u stanju da odgode postizanje ličnog zadovoljstva, imaju nestalne i površne emocije, spontani su, teško im je održati pažnju i često se ne pridržavaju društvenih normi (Block \& Kremen, 1996).

Posljedice ponašanja obje kategorije osoba mogu biti funkcionalne i disfunkcionalne. Naime, odgovornost i organizacija osoba koje su sklone pretjeranoj kontroli, kao i njihova sposobnost odlaganja postizanja ličnog zadovoljstva jesu socijalno poželjne osobine kada je u pitanju postizanje npr. poslovnih uspjeha. Sa druge strane, otvorenost i spontanost osoba koje imaju poteškoće u kontroli impulsa, njihova sklonost ispoljavanju topline i prijateljstva je poželjna osobina koja utiče na stvaranje kvalitetnih interpersonalnih odnosa. Ove osobe mogu imati poteškoće ukoliko radi nemogućnosti kontrole impulsa počnu ispoljavati ponašanja kojima krše društvene norme (Letzring, Block, \& Funder, 2005). 
Ego-otpornost je crta ličnosti koja se ispoljava u modifikovanju i prilagođavanju nivoa Ego-kontrole u skladu sa zahtjevima okruženja. Prema Blokovoj teoriji (Block \& Kremen, 1996), osobe sa povišenom Ego-otpornosti su u stanju da modifikuju svoj nivo kontrole, tj. da ga snize ili povećaju u skladu sa situacijom u kojoj se nalaze. Češće imaju pozitivne emocije i viši nivo samopouzdanja. Mentalno su zdraviji od osoba sa nižim nivoom Ego-otpornosti. Osobe sa niskom Ego-otpornosti su uvijek na istom nivou ispoljavanja impulsa, bez obzira na situaciju u kojoj se nalaze. $U$ stresnim situacijama djeluju kao da su blokirani i često ponavljaju isto ponašanje iako ih ono ne vodi rješavanju situacije.

Drugi aspekt otpornosti koji je analiziran u ovom radu je definisan kroz interpersonalne $\mathrm{i}$ intrapersonalne kapacitete osobe koji utiču na adaptaciju i toleranciju na stres i negativne životne događaje. Kapaciteti otpornih osoba su mnogobrojni i odnose se na širok spektar zaštitinih faktora, kao što je uspješno korištenje sopstvenih vještina, socijalna zrelost, orijentacija na uspjeh i prosocijalno ponašanje. Otporne osobe imaju i pozitivnu sliku o sebi i visoko razvijen internalni lokus kontrole, optimističnije su, emocionalno stabilnije, posjeduju adekvatne interpersonalne vještine i imaju pozitivan stav prema životu, na koji gledaju kao da ima značenje i svrhu. Imaju viši nivo edukacije i posjeduju sposobnosti za planiranje i organizaciju (Herman et al., 2011).

Broj studija koje se bave ispitivanjem otpornosti je naglo porastao u posljednih 20 godina jer su mladi mnogo više izloženi različitim rizicima (Goldstein \& Brooks, 2013). U današnje vrijeme teško je ublažiti efekte rizičnih faktora, čak su i djeca koja nisu bila izložena direktno traumi, nekom stresnom događaju ili koja nisu iskusila anksioznost, posredno izložena navedenom preko drugih ljudi koji ih okružuju. U cilju identifikacije varijabli koje predviđaju otpornost prilikom suočavanja sa poteškoćama nastoje se razvijati modeli koji će imati adekvatnu i efektivnu primjenu.

Aspekti u kojima se razlikuju Ego-otpornosti i otpornosti su: a) Ego-otpornost je osobina ličnosti, dok je otpornost dinamički razvojni proces; b) Ego-otpornost ne podrazumijva izloženost teškoćama, dok otpornost po definiciji to nužno podrazumijva (Luthar, Ciccheti, \& Becker, 2000).

Društveno neprihvatljivo ponašanje se može definisati kao ponašanje koje nije u skladu sa zakonskim i moralnim normama i koje kao takvo izaziva društvenu reakciju sa ciljem njegovog redukovanja (Koledin, 2016). Različite manifestacije društveno neprihvatljvog ponašanja negativno utiču kako na pojedinca, tako i na njegovo okruženje, a posljedice takvog ponašanja mogu biti neznatne, sa jedne strane ali i nepopravljive, sa druge strane. Faktori koji utiču na ispoljavanje društveno neprihvatljivog ponašanja mogu se $u$ najopštijem smislu podijeliti u dvije grupe i to endogeni ili unutrašnj (psihološki) i egzogeni ili spoljašnji (socijalni). Grupu unutrašnjih faktora pored neuropsiholoških i genetskih, čine osobine ličnosti, dok grupu spoljašnjih čini uže i šire socijalno okruženje.

Međedović (2009) navodi ličnost kao jedan od najznačajnijih eksplanatornih konstrukata u kriminologiji, a Petofaktorski model ličnosti procijenjuje kao uspješan eksplanatorni koncept. Osim toga, u psihološkoj literaturi naglašeno je da se karakteristike ličnosti tretiraju kao psihološki faktori vulnerabilnosti za nastanak 
afektivnih poremećaja, a postoji ideja da se čak određene kategorije poremećaja definišu uz pomoć petofaktorskog modela (Marić, 2010). Pored Petofaktorskog modela ličnosti, za predviđanje sklonosti društveno neprihvatljivom ponašanju značajnim se pokazao i inventar ličnosti Velikih pet +2 . Kao najznačajniji prediktori društveno neprihvatljivog ponašanja iz ovog modela izdvajaju se crte Savjesnost i Agresivnost (Smederevac, Mitrović, i Čolović, 2010). Savjesnost se odnosi na planski i ka cilju usmjerno, odgovorno i posvećeno ponašanje. Osoba sa povišenjem na ovoj crti ima izraženu sposobnost organizacije i samodiscipline, koja pozitivno utiče na mogućnost da se slijede društvene norme i pravila, odgađa zadovoljstvo i kontrolišu impulsi. Rezultati istraživanja su pokazali da je niska Savjesnosti povezana sa slabijom samokontrolom u djetinjstvu i antisocijalnim ponašanjem (Gungea, Jaunky \& Ramesh, 2017). Agresivnost je crta koja se ispoljava kroz učestale i intenzivne agresivne impulse i agresivne reakcije (Smederevac, at al. 2010). Agresivne osobe su manipulativne, cinične, nepristojne, neprijatne i sumnjičave prema namjerama drugih (Gungea, at al., 2017).

Istraživanja koja su se bavila ispitivanjem odnosa između društveno neprihvatljivog ponašanja i Ego-otpornosti su rijetka. Milioni, Alessandri, Eisenberg, Vecchione, \& Caprara Vittorio (2015) ispitivali su prediktivnu moć Ego-otpornosti u kontekstu predviđanja problema u ponašanju, na uzorku osoba ranog odraslog doba. Došli su do rezultata da je Ego-otpornost odličan prediktor internalizovanih problema u ponašanju, koji se manifestuju kroz povišenu depresiju i anksioznost. Ego-otpornost se nije pokazala kao statistički značajan prediktor eksternalizovanih problema u ponašanju, pri čemu su vrijednosti bile na granici značajnosti. Do sličnih rezultata su došli Huey \& Weisz (1997) koji su ispitivali povezanost Egokontrole i Ego-otpornosti sa poteškoćama u ponašanju na uzorku djece koja su već manifestovala probleme u ponašanju. Pokazalo se da je slaba Ego-kontrola najbolji prediktor eksternalizovanih problema u ponašanju, dok je slaba Ego-otpornost $u$ kombinaciji sa slabom Ego-kontrolom značajan prediktor internalizovanih problema u ponašanju. Block, Block, \& Keyes (1988) identifikovali su povezanost između niske Ego-otpornosti i zloupotrebe psihoaktivnih supstanci.

Kada su u pitanju istraživanja o odnosu između otpornosti u kontekstu intrapersonalnih i intrepersonalnih kapaciteta koji utiču na suočavanje sa stresom i društveno neprihvatljivog ponašanja, uglavnom su provođena u smijeru ispitivanja faktora rizika i zaštite koji smanjuju ili povećavaju otpornost osobe, a time i ispoljavanje društveno neprihvatljivog ponašanja. McKnight \& Loper (2002) su na osnovu istraživanja koje su provele na uzorku adolescenata došle do rezultata da su faktori zaštite koji su povezani sa otpornošću (nekonzumiranje psihoaktivnih supstanci, izražen osjećaj prihvatanja i ljubavi, osjećaj da im roditelji vjeruju, uvjerenje da nastavnici imaju fer odnos prema njima i religioznost) značajni prediktori društveno neprihvatljivog ponašanja. Gökmen (Arslan, 2016) ispitivao je medijacijsku ulogu otpornosti i samopoštovanja između zlostavljanja u djetinjstvu i emocionalnih problema i poremećaja u ponašanju. Otpornost se pokazala kao značajan prediktor i emocionalnih problema i poremećaja u ponašanju. Takođe, rezultati upućuju na zaključak da i otpornost i samopoštovanje imaju značajnu 
medijacijsku ulogu između zlostavljanja u djetinjstvu i emocionalnih problema i poremećaja u ponašanju. Ziaian, De Anstiss, Antoniou, Baghurst, \& Sawyer (2012) došli su do zaključka da adolescenti koji imaju depresivne simptome, emocionalne poteškoće i probleme u ponašanju imaju slabiju otpornost.

Osnovni cilj istraživanja je ispitati da li otpornost, analizirana kroz dva aspekta (RSA i Ego-otpornost) statistički značajno predviđa dio varijanse u društveno neprihvatljivom ponašanju, kada se kontroliše varijansa koju objašnjavaju dimenzije Agresivnost i Savjesnost inventara ličnosti Velikih pet+2.

U skladu sa prirodom konstrukta otpornosti, a i uvažavajući navedene rezultate dosadašnjih istraživanja, očekivano je da će osobe koje imaju slabiju otpornost imati poteškoće u adaptaciji na socijalne norme, te da će se te poteškoće manifestovati ispoljavanjem društveno neprihvatljivog ponašanja. Radi niže Ego-otpornosti, osoba neće biti u mogućnosti da na adekvatan način uskladi ispoljavanje impulsa uslovima sredine u kojoj se nalazi, što će rezultirati ponašanjem koje nije u skladu sa važećim socijalnim normama. Sa druge strane, ukoliko osoba nema razvijene interpersonalne i intrapersonalne kapacitete koji su nužni za adaptaciju prilikom suočavanja sa stresnim životnim događajima, sasvim je očekivano da će u uslovima pojačanog stresa reagovati neadekvatno, pri čemu je jedan od načina reagovanja upravo društveno neprihvatljivo ponašanje.

\section{Problem istraživanja}

Problem istraživanja je operacionalizovan kao ispitivanje mogućnosti predviđanja društveno neprihvatljivog ponašanja na osnovu otpornosti. Konstrukt otpornosti je analiziran kroz dva aspekta. Prvi se odnosi na intrapersonalne i interpersonalne kapacitete osobe koji utiču na adaptaciju i toleranciju na stres $\mathrm{i}$ negativne životne događaje, dok je drugi aspekt otpornost kao crta ličnosti, tj. Egootpornost.

Pored mjera otpornosti u prediktivni model su uključene i dimenzije Savjesnost i Agresivnost iz inventara Velikih pet +2 , jer su rezultati istraživanja pokazali da je ličnost jedan od najznačajnijih eksplanatornih konstrukata kriminogenog ponašanja (Međedović, 2009). Iako su ova istraživanja provođena u različitim kontekstima, rezultati su upućivali na zaključke koji su bili slični. Savjesnost i Agresivnost su dvije dimenzije ličnosti koje su se pokazale kao najbolji prediktori društveno neprihvatljivog ponašanja (Smederevac et al., 2010) niska saradljivost, sklonost ka prepirci i svađi, zajedljivosti (indikatori visoke Agresivnosti), ali takođe i slaba motivacija za postignućem i snižena sposobnost organizacije pri ispunjenju zadataka (indikatori niske Savjesnosti) odlikuju kriminogene ličnosti (Međedović, 2009).

\section{Hipoteze istraživanja}

Kako se na osnovu rezultata dosadašnjih istraživanja (Marušić, 2019; Međedović, 2009; Smederevac et al., 2010) pokazalo da su Savjesnost i Agresivnost statistički značajni prediktori društveno neprihvatljivog ponašanja, hipoteza je da će ove dvije dimenzije biti statistički značajni prediktori društveno neprihvatljivog 
ponašanja i u aktuelnom istraživanju. Pored toga, hipoteza je da će otpornost i Egootpornost biti statistički značajni prediktori društveno neprihvatljivng ponašanja kada se statistički kontroliše varijansa Savjesnosti i Agresivnosti.

\section{Metod}

\section{Uzorak i procedura}

Istraživanje je realizovano na prigodnom uzorku od 384 ispitanika iz populacije učenika završnih razreda srednjih škola, sa područja Republike Srpske (Bosna i Hercegovina). U uzorku je više ispitanika ženskog pola (60.4\%). Starost se kreće u rasponu od 16 do 19 godina, a prosječna vrijednost je 17.11 godina, uz standardnu devijaciju od 0.88 godina.

Primjenjena je hijerarhijska regresiona anliza. U model regresione analize, $\mathrm{u}$ prvom koraku uključene su dimenzije ličnosti Agresivnost i Savjesnost, a u drugom koraku uključene su Otpornosti i Ego-otpornost. Cilj istraživanja je ispitati da li otpornost statistički značajno predviđa dio varijanse u društveno neprihvatljivom ponašanju, kada se kontroliše varijansa koju objašnjavaju Agresivnost i Savjesnost iz inventara ličnosti Velikih pet +2 .

\section{Instrumenti}

Za ispitivanje otpornosti kao intrapersonalnih i interpersonalnih kapaciteta individue, korištena je Skala otpornosti za odrasle (Resilience Scale for Adults RSA; Hjemdal, Friborg, Martinussen \& Rosenvinge, 2001). Izvorna verzija skale je sadržavala 33 stavke i mjerila je 5 dimenzija i to: Individualne kapacitete (Personal strenght), Socijalne kompetencije (Social comeptenece), Strukturalni stil (Structured style), Porodičnu koheziju (Family cohesion) i Socijalne resurse (Social resources). U ovom istraživanju je korištena prevedena i adaptirana skala (Vujović \& Petronić, 2019) koja takođe sadrži 33 stavke, ali mjeri jednu dimenziju. I u ovom istraživanju se nakon faktorske analize pokazalo da skala mjeri jednu dimenziju, dok KronbahovAlfa koeficijent koji iznosi $\alpha=.934$ upućuje na zaključak da je pouzdanost skale izuzetno visoka. Veći broj bodova na skali znači jaču otpornost. U zavisnosti od toga koliko se slažu sa navedenim tvrdnjama, ispitanici odgovaraju zaokruživanjem jednog od pet ponuđenih odgovora.

Za ispitivanje otpornosti kao crte korištena je Skala Ego-otpornosti (EgoResiliency Scale - ER89; Block \& Kremen, 1996). Skalu čini 14 stavki, Likertovog je tipa, a ispitanici odgovaraju zaokruživanjem jednog od četiri ponuđena odgovora, u skladu sa tim koliko se stavka odnosi na njih. Pouzdanost skale na ovom uzorku je visoka $(\alpha=.819)$.

Iz Upitnika Velikih pet +2 (Semderevac, Mitorvić \& Čolović, 2010) korištene su skale za ispitivanje dimenzija Agresivnost i Savjesnosti, s obzirom na to da su se u prethodnim istraživanjima pokazale kao dobri prediktori maloljetničke delinkvencije. Skale su petostepene, Likertovog tipa. 
Skala socijalno neprihvatljivog ponašanja (Koledin, 2016) ispituje 25 oblika društveno neprihvatljivih ponašanja. Ispitanici odgovaraju zaokruživanjem jednog od tri ponuđena odgovora (veoma često, nekoliko puta, nikada), u skladu sa tim koliko su često svaki od navedenih oblika ponašanja manifestovali. Niži skor na skali ukazuje na rjeđe manifestovanje društveno neprihvatljivog ponašanja, dok viši skor ukazuje na češće manifestovanje društveno neprihvatljivog ponašanja. Koeficijent pouzdanosti je i za ovu skalu veoma visok i iznosi $\alpha=.924$. Skalu čine stavke koje se odnose na različite oblike društveno neprihvatljivih ponašanja, od bježanja od kuće i zloupotrebe psihoaktivnih supstanci i alkohola, preko različitih oblika nasilnog ponašanja, do ponašanja koja se svrstavaju u teška krivična djela.

\section{Rezultati}

Za otkrivanjemultivarijatnih ekstremnih rezultata izračunatesu Mahalanobisove udaljenosti reziduala. U model su uključena tri prediktora pa je kritična vrijednost za procjenu rezultata kao ekstremnog 18.47. Na osnovu rezultata može se zaključiti da od 384 ispitanika, postoji samo jedan razultat koji ima Mahalanobisovu udaljenost veću od dozvoljene (30.39). Kako bi se ispitalo da li ovaj rezultat utiče na rezultate modela, utvrđena je vrijednost Kukove distance (Cook's Distance). Rezultati pokazuju da maksimalna Kukova distanca iznosi .078 što znači da ne premašuje 1, što znači da će i rezultati ovog ispitanika biti zadržani u analizi jer ne narušavaju rezultate modela.

Linearnost korelacija među varijablama utvrđena je na osnovu dijagrama rasturanja. Uvidom u grafikon broj 1 na kome su grafički prikazane korelacije među varijablama može se zaključiti da pretpostavka o linearnosti odnosa među varijablama nije narušena jer među njima ne postoji krivolinijski odnos. 


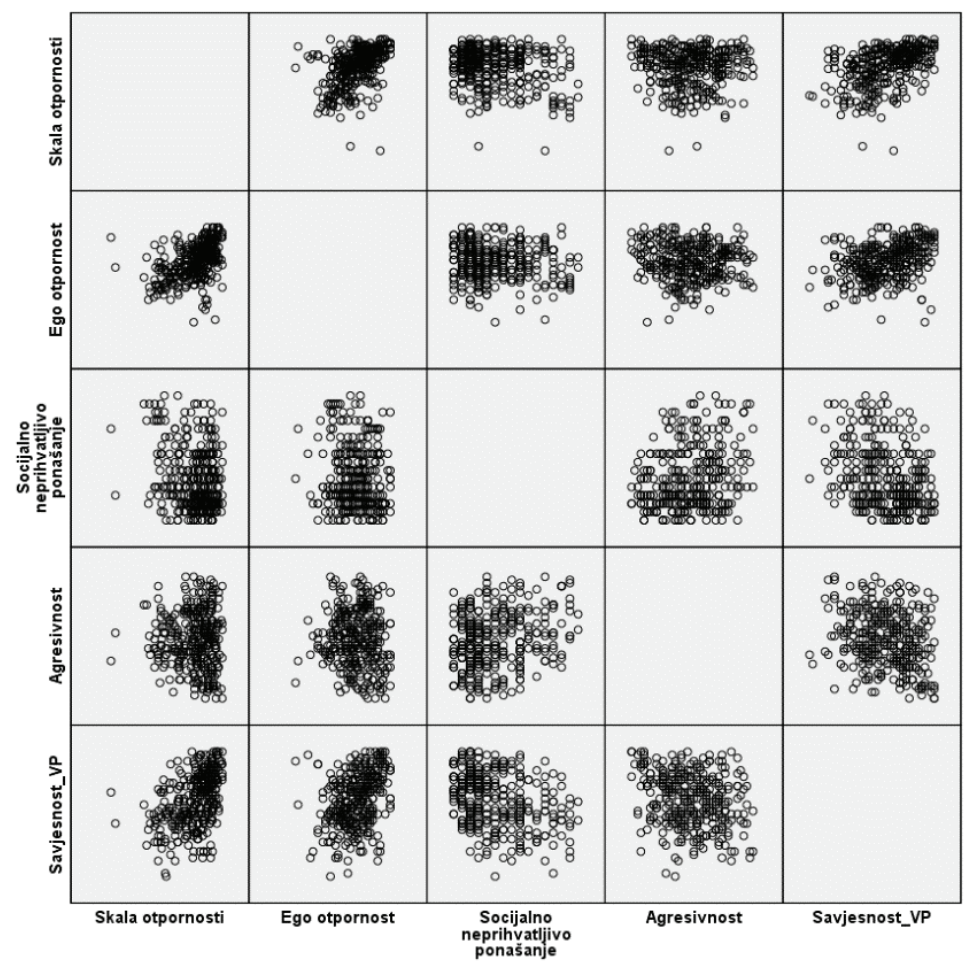

Grafikon 1. Korelacija između varijabli

Pretpostavka o normalnoj raspodjeli reziduala ispitana je na osnovu Normal P-P Plot dijagrama, histograma i deskriptivnih pokazatelja za distribuciju reziduala. Rezultati P-P Plot dijagrama (grafikon broj 2) pokazuju da se tačke raspoređuju oko prave linije koja predstavlja normalnu raspodjelu, iako postoji odstupanje u području negativnih standardizovanih vrijednosti. 


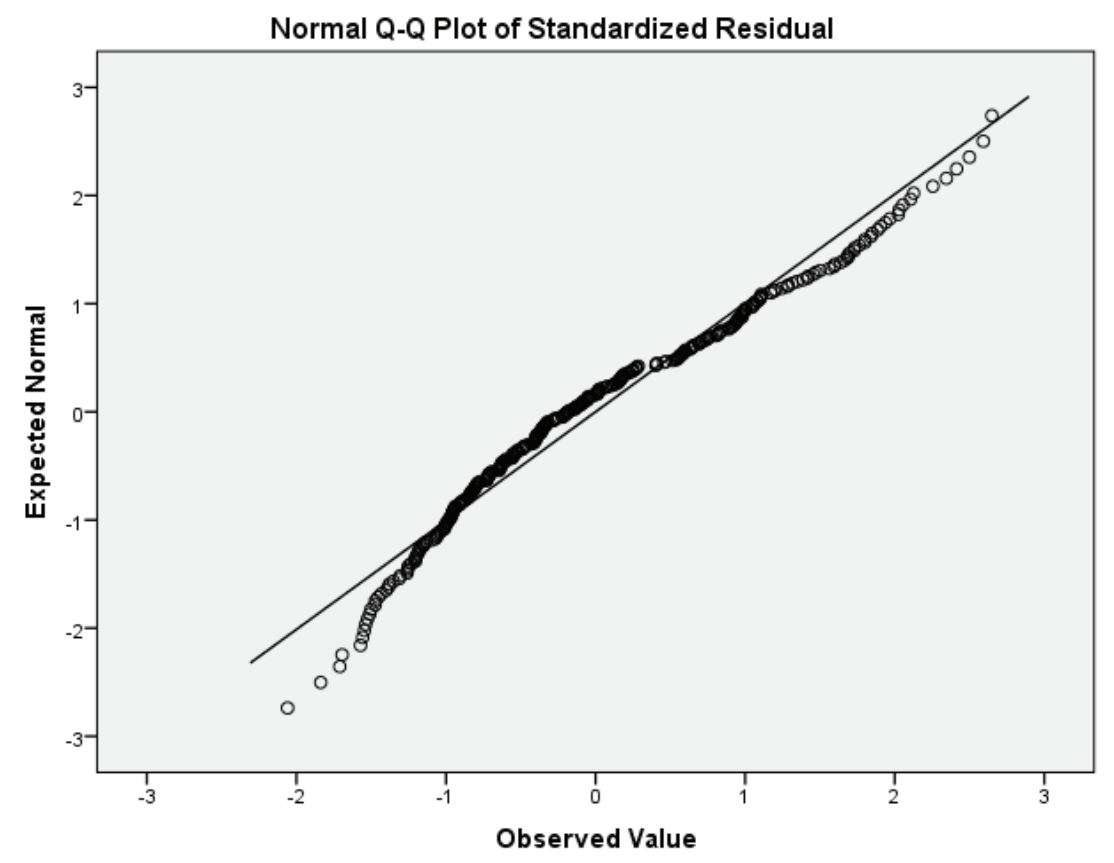

Grafikon 2. Q-Q dijagram standradizovanih reziduala

Detaljniji uvid može se ostvariti preglednom histograma na osnovu kojeg se može zaključiti da su standardizovane vrijednosti reziduala blago pozitivno asimetrične (grafikon broj 3). Deskriptivni statistički pokazatelji, takođe ukazuju da je narušena pretpostavka o normalnoj raspodjeli, jer je vrijednost skjunisa $(0.501)$ više od tri puta veća od njegove standardne greške (0.136). Ipak, ukoliko se ima u vidu da vrijednost skujunisa ne prelazi 1 , to znači da asimetrija, iako postoji, nije previše izražena. Takođe, broj ispitanika u uzorku (348) statistički je uticao na smanjenje standardne greške skjunisa, te s obzirom na to da distribucija standardizovanih reziduala ima oblik zvonaste krive, zadovoljeni su uslovi za primjenu regresione analize. 


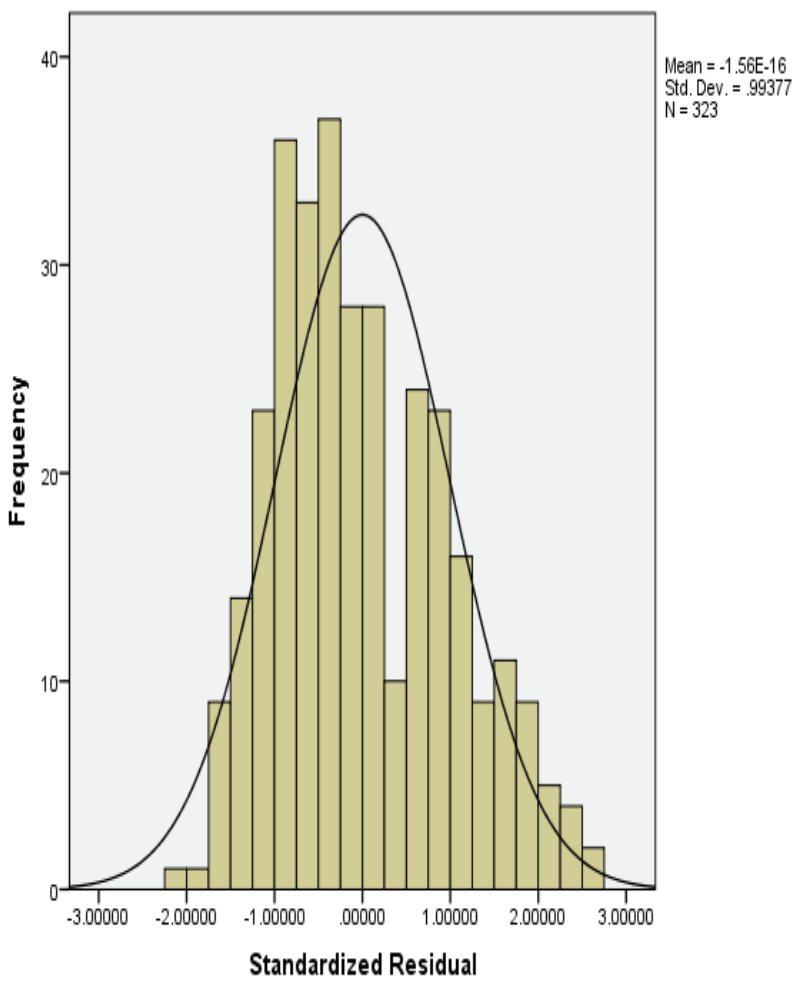

Grafikon 3. Histogram standardizovanih reziduala

Multikolinearnost i singularnost provjerena je korelacijom među prediktorima (tabela 1). Najveća korelacija zabilježena je između otpornosti i Ego-otpornosti $r$ $=.46$. Iako je ovo najveća korelacija, ne ukazuje na multikolinearnost jer je manja od preporučene granične vrijednosti .7. Takođe, parametri kojima se provjerava multikolinearnost pokazuju da ovaj problem nije izražen u podacima jer je najmanja tolerancija .70, a najveća vrijednost VIF iznosi 1.44.

Tabela 1

Matrica korelacija među prediktorima

\begin{tabular}{lcccc}
\hline & Agresivnost & Savjesnost & Otpornost & Ego otpornost \\
\hline 1. Soc. neprihvatljivo ponašanje & -.24 & -.03 & -.08 & -.24 \\
2. Agresivnost & & -.24 & -.03 & -.08 \\
3. Savjesnost & & & .44 & .33 \\
4. Otpornost & & & & .45 \\
\hline
\end{tabular}

Sumirenjem do sada prikazanih rezultata može se zaključiti da je preliminarnom analizom utvrđeno da su zadovoljene pretpostavke za primjenu hijerarhijske višestruke linearne regresije. U prvom koraku unijete su dimenzije Agresivnost i Savjesnost iz modela Velikih 5+2. Model u koji su uključene samo dimenzije 
Agresivnost i Savjesnosti statistički je značajan i objašnjava 14.2\% varijanse društveno neprihvatljivog ponašanja. Nakon što su u model uključene otpornost i Ego-otpornost on ostaje statitički značajan, pri čemu je sada objašnjeno ukupno 16\% varijanse društveno neprihvatljivog ponašanja. Dakle, otpornost i Ego-otpornost su objasnili dodatnih $1.8 \%$ društveno neprihvatljivog ponašanja. Rezultati glavne analize prikazani su u tabeli broj 2 .

Tabela 2

Otpornost i Ego-otpornost kao prediktori društveno neprihvatljivog ponašanja

\begin{tabular}{lccc}
\hline & Korak prvi & Korak drugi & $s r$ \\
\hline Agresivnost & $\beta$ & $\beta$ & .18 \\
Savjesnost & $.18^{* *}$ & $.19^{* *}$ & -.21 \\
Otpornost & $-.29 * *$ & $-.24 * *$ & -.13 \\
Ego-otpornost & & $-.16^{*}$ & .05 \\
& $R=.38$ & .06 & Model u cjelini \\
& $R^{2}=.142$ & & $R=.40$ \\
$R^{2}=.137$ & Promjena $R^{2}=.017$ & $R^{2}=.160$ \\
& $F(2,320)=26.58^{* *}$ & $F_{c h n}(2,318)=3.23^{*}$ & $c R^{2}=.149$ \\
& & & $F(4,318)=15.09 * *$ \\
\hline
\end{tabular}

Napomena. ${ }^{*} p<.05 ; * * \mathrm{p}<.01 ; s r-$ semiparcijalna korelacija; $R$ - koeficijent multiple korelacije; $R^{2}$ - koeficijent multiple determinacije; $F_{c h n}$ - statistik promjene u procentu objašnjene varijanse; $c R^{2}$ - korigovani $\mathrm{R}^{2}$.

Analizirana je i prediktivna vrijednost pojedinačnih prediktora. U skladu sa polaznim pretpostavkama, Agresivnost i Savjesnost su se pokazale kao statistički značajni prediktori društveno neprihvatljivog ponašanja. Savjesnost je najsnažniji prediktor, a rezultati upućuju na zaključak da osobe koje su odgovorne i posvećene, ciljem usmjerene i disciplinovane rjeđe ispoljavaju društveno neprihvatljivo ponašanje.

Nakon Savjesnosti, prema predikcijskoj moći, ističe se Agresivnost. Pozitivan regresioni koeficijent upućuje na zaključak da pojedinici koji su cinični, neprijatni, nepristojini i sumnjičavi prema namjerama drugih ljudi, češće ispoljavaju društveno neprihvatljivo ponašenje. Kod ovih osoba je smanjena empatija i manje im je stalo do osjećanja koje njihovo ponašanje izaziva kod drugih ljudi, te stoga manje nastoje da kontrolišu svoje agresivne impulse i reakcije.

Od varijabli koje su uključene u model u drugom koraku, samo se otpornost (koja se odnosi na intrapersonalne i interpersonalne kapacitete osobe koji utiču na adaptaciju i toleranciju na stres i negativne životne događaje) pokazala kao statistički značajan prediktor. Osobe koje su otporne, posjeduju interpersonalne i intrapersonalne kapacitete, socijalnu zrelost, orijentaciju na uspjeh i prosocijalno ponašanje i rijeđe se upuštaju u društveno neprihvatljivo ponašanje zbog toga što imaju veću sposobnost da se adaptiraju i viši prag tolerancije na stres i negativne životne događaje, emocionalno su stabilnije i posjeduju adekvatne interpersonalne vještine. 
Ego-otpornost se u ovom modelu nije pokazala kao statistički značajan prediktor društveno neprihvatljivog ponašanja. Interesantan je podatak da se ovaj konstrukt pokazao kao statistički značajan prediktor društveno neprihvatljivog ponašanja kada je primjenjena regresiona analiza na pojedinačnim prediktorima $(F(1,381)=4.84, p=.028, \beta=-.11, p=.028)$, a da nije bio statistički značajan kada je uključen u drugom koraku, kao dodatni prediktor uz Skalu otpornosti RSA. To znači da je aspekt otpornosti koji se odnosi na intrapersonalne i interpersonalne kapacitete dominantan u predviđanju društveno neprihvatljivog ponašanja i da ovaj aspekt otpornosti objašnjava i onaj dio varijanse društveno neprihvatljivog ponašanja koji samostalno predviđa Ego-otpornost, shvaćena kao relativno trajna tendencija ka modifikovanju i usklađivanju kontrole ispoljavanja impulsa zahtjevima situacije.

\section{Diskusija i zaključak}

Osnovni cilj istraživanja bio je ispitati da li otpornost, analizirana kroz dva aspekta (RSA i Ego-otpornost) statistički značajno predviđa dio varijanse u društveno neprihvatljivom ponašanju, kada se kontroliše varijansa koju objašnjavaju dimenzije Agresivnost i Savjesnost inventara ličnosti Velikih pet +2 . Primjenjena je hijerarhijska regresiona analiza nakon što je utvrđeno da podaci zadovoljavaju uslove za primjenu ove multivarijatne tehnike. Rezultati su pokazali da su dimenzije ličnosti Savjesnost i Agresivnost statistički značajni prediktori društveno neprihvatljivog ponašanja. Ovaj rezultat je u skladu sa dosadašnjim istraživanjima (Marušić, 2019; Međedović, 2009, Smederevac et al., 2010) i polaznim pretpostavkama u ovom istraživanju.

U hijerarhijskoj regresionoj analizi, pored dimenzija ličnosti Savjesnost i Agresivnost, samo se otpornost shvaćena kao interpersonalni i intrapersonalni kapacitet osobe za adaptaciju i toleranciju na stres i negativne životne događaje pokazala kao statistički značajan prediktor društveno neprihvatljivog ponašanja, dok Ego-otpornost nije. To znači da otpornost kao interpersonalni i intrapersonalni kapacitet objašnjava i onaj dio varijanse društveno neprihvatljivog ponašanja koji samostalno predviđa Ego-otpornost, tj. otpornost shvaćena kao osobina ličnosti, pa se na osnovu ovih rezultata može zaključiti da je otpornost mjerena skalom RSA obuhvatniji prediktor društveno neprihvatljivog ponašanja od otpornosti koja je shvaćena kao crta ličnosti. Kada je poređenje prediktivne moći svih pojedinačnih prediktora uključenih u model u pitanju i dalje su najdominantnije dimenzije inventara Velikih pet +2 (Savjesnost i Agresivnost), nakon čega slijedi otpornost (RSA).

Na osnovu dobijenih rezultata moguće je izvesti zaključak da su osobe koje imaju slabiju otpornost sklonije manifestovanju društveno neprihvatljivog ponašanja. To je u skladu sa rezultatima prethodnih istraživanja (Milioni et al., 2015; Huey \& Weisz, 1997; Block et al.,1988), ali i u skladu sa konceptom konstrukta otpornosti. Osobe koje nemaju kapacitete da se na adekvatan način suoče sa stresnim događajima i da očuvaju mentalno zdravlje u stresnim okolnostima, češće će pribjegavati različitim oblicima društveno neprihvatljivog ponašanja kako bi povratili ravnotežu 
(konzumiranjem psihoaktivnih supstanci, npr.) ili pak radi frustracije koja se javlja uslijed nesposobnosti da se suoče sa stresom ispoljavati različite oblike nasilnog ponašanja.

Osobe sklone društveno neprihvatljivom ponašanju nemaju razvijene intrapersonalne i interpersonalne kapacitete ili ih imaju slabije razvijene, te je za očekivati da će njihova otpornost biti slabija u odnosu na osobe koje se ponašaju u skladu sa društvenim normama. Jedna od karakteristika otpornosti jeste prihvatanje društvenih normi, što olakšava svakodnevno funkcionisanje otporne osobe. Osobe sklone društveno neprihvatljivom ponašanju nemaju povjerenje u druge ljude, kao ni u sopstvene sposobnosti. Uglavnom dolaze iz porodica u kojima preovladava negativa emocionalna klima, ali i međusobno nepoštovanje među članovima, kao i učestali konflikti (Koledin, 2016).

Dobijeni rezultat koji se odnosi na to da Ego-otpornost nije statistički značajan prediktor društveno neprihvatljivog ponašanja $u$ konačnom modelu, moguće je objasniti time što je ispitivano eksternalizovano društveno neprihvatljivo ponašanje, koje se ni u prethodnim istraživanjima (Milioni et al., 2015) nije pokazalo kao značajan korelat Ego-otpornosti, za razliku od internalizovanog društveno neprihvatljivog ponašanja, kao što su depresija i anksioznost.

Dobijeni rezultati otvaraju prostor za preventivno djelovanje na društveno neprihvatljivo ponašanje u smijeru jačanja interpersonalnih, ali i intrapersonalnih kapaciteta osobe, a time $\mathrm{i}$ otpornosti u cjelini. Asertivnost je vještina koja se uči i kroz koju je moguće raditi na poboljšanju socijalnih kompetencija pojedinca. Razvijanjem vještine komunikacije, doći će do jačanja socijalnih resursa u smislu izgradnje odnosa na povjerenju, kako sa prijateljima, tako i sa članovima porodice. Struktuiran stil je moguće izgraditi još u ranom djetinjstvu kroz radne navike. Formalnim obrazovanjem, radne navike se još više učvršćuju i na taj način se uči značaj strukture i planiranja vremena u kontekstu postizanja postavljenih ciljeva. Jačanjem svih do sada navedenih aspekata jača se i samopouzdanje i vjera u sopstveno rasuđivanje.

Preporuke za buduća istraživanja se odnose na otklanjanje ograničenja ovog istraživanja. Naime, bilo bi korisno u uzorak uključiti i osobe koje su registrovane u kontekstu manifestovanja društveno neprihvatljivog ponašanja, te napraviti komparativnu analizu između njih i osoba koje takvo ponašanje nisu manifestovale i na taj način analizirati značaj otpornosti. Time bi bio otklonjen nedostatak upotrebe skale samoiskaza koja je primjenjena u ovom istraživanju sa ciljem ispitivanja frekventnosti ispoljavanja društveno neprihvatljivog ponašanja. Bilo bi zanimljivo $\mathrm{i}$ analizirati polne razlike među ispitanicima u odnosu na razvijenost otpornosti, sa jedne strane i frekventnosti ispoljavanja društveno neprihvatljivog ponašanja, sa druge strane, pri čemu bi u tom slučaju bilo nužno poštovati strukturu ispitanika po ugledu na polnu strukturu u populaciji.

Važno je naglasiti da je doprinos mjera otpornosti od $1,7 \%$ procentu objašnjene varijanse društveno neprihvatljivog ponašanja vrlo skroman, te se u cilju adekvatnijeg objašnjenja ove pojave za buduća istraživanja preporučuje da se nacrt istraživanja proširi većim brojem varijabli. Konkretnije, bilo bi korisno uključiti u istraživanje i 
analizu socijalnog okruženja ispitanika (porodični odnosi i atmosfera, odnosi u školi, odnosi sa vršnjacima, itd.) i u tom kontekstu, otpornost posmatrati kao intervenišuću varijablu, s obzirom na to da je društveno neprihvatljivo ponašanje ishod kombinacije odnosa između sredine i ličnosti. Na taj način bi otpornost bila jedan od posrednika, pri čemu bi se krenulo od pretpostavke da visoka otpornost može da neutrališe neadekvatno socijalno okruženje i amortizuje njegov uticaj na optimalan razvoj individue, a time i na redukciju ispoljavanja društveno neprihvatljivog ponašanja.

S obzirom na to da je fenomen otpornosti i dalje nedovoljno jednoznačno definisan, te da postoje različiti pristupi istraživanju ovog fenomena, svako novo istraživanje daje odgovore na neka pitanja, ali i otvara mnoštvo novih, na koja tek treba odgovoriti. U tom kontekstu su i rezultati ovog istraživanja odgovorili na pitanje o mogućnostima predviđanja društveno neprihvatljivog ponašanja na osnovu otpornosti, ali i otvorili niz novih pitanja o odnosu ispitivanih fenomena, koja su svakako podsticaj za buduća istraživanja.

\section{Reference}

Arslan, G. (2016). Psychological maltreatment, emotional and behavioral problems in adolescents: The mediating role of resilience and self-esteem. Child Abuse \& Neglect, 52, 200-209.

Block, J., \& Kremen, A. M. (1996). IQ and Ego-Resiliency: Conceptual and Empirical Connections and Separateness. Journal of Personality and Social Psychology, $70(2), 349-361$.

Block, J., Block, J. H., \& Keyes, S. (1988). Longitudinally Foretelling Drug Usage in Adolescence: Early Childhood Personality and Environmental Precursors. Child Development, 59(2), 336-355.

Goldstein, S., \& Brooks, B. R. (2013). Why Study Rezilience? In S. Goldstein, \& B. R. Brooks (Eds.), Handbook of Rezilience in Childern (str. 3-14). New York: Sringer.

Gungea, M., Jaunky, V. C., \& Ramesh, V. (2017). Personality traits and juvenile delinquency. International Journal of Conceptions on Management and Social Sciences, 5(1), 42- 46.

Hjemdal, O., Friborg, O., Martinussen, M., \& Rosenvinge, J. H. (2001). Mestring og psykologisk motstandsdyktighet hos voksne: Utvikling og foreløpig validering av et nytt instrument [Preliminary results from the development and validation of a Norwegian scale for measuring adult resilience]. Tidsskrift for Norsk Psykologforening, 38(4), 310-317.

Herman, H., Stewart, E. D., Diaz-Granados, N., Berger, L. E., Jackson, B., \& Yuen, T. (2011). What Is Resilience? La Revue Canadienne de Psychiatrie, 56(5), 258-265.

Huey, S. J., \& Weisz, J. R. (1997). Ego Control, Ego Resiliency, and the Five-Factor Model as Predictors of Behavioral and Emotional Problems in Clinic-Referred Children and Adolescents. Journal of Abnormal Psychology, 106(3), 404-415.

Koledin, G. (2016). Kriminogeno ponašanje i mogućnost predviđanja. Banja Luka: Grafid. 
Letzring, T. D., Block, J., \& Funder, D. C. (2005). Ego-control and ego-resiliency: Generalization of self-report scales based on personality descriptions from acquaintances, clinicians, and the self. Journal of Research in Personality, 39(4), $395-422$.

Luthar, S. S., Ciccheti, D., \& Becker, B. (2000). The Construct of Resilience: A Critical Evaluation an Guidelines for Future Work. Child Development, 71(3), 543-562.

Marić, M. (2010). Osobine ličnosti, životni događaji i anksioznost adolescenata. Primenjena psihologija, 3(1), 39-57.

Marušić, I. (2019). Odnos morala, ličnosti i negativnog ponašanja na društvenim mrežama (Neobjavljena doktorska disertacija). Sveučilište u Zadru, Zadar.

Međedović, J.(2009). Bazična struktura ličnosti i kriminalitet. Primenjena psihologija, 2(4), $339-367$.

Milioni, M., Alessandri, G., Eisenberg, N., Vecchione, M., \& Caprara Vittorio, G. (2015). The predictive role of ego-resiliency on behavioural problems. European Journal of Developmental Psychology, 12(2), 220-233.

McKnight, L. R., \& Loper, A. B. (2002). The effect of risk and resilience factors on the prediction of delinquency in adolescent girls. School Psychology International, 23(2), 186-198.

Vujović, G. i Petronić, Đ. (2019). Validacija skale otpornosti za odrasle (RSA). Nauka i stvarnost, 13(2), 206-218.

Smederevac, S., Mitrović, D.iČolović,P.(2010). Velikih petplus dva:Primenaiinterpretacija [Big Five Plus Two: Manual for administration and interpretation]. Beograd, Srbija: Centar za primenjenu psihologiju.

Ziaian, T., de Anstiss, H., Antoniou, G., Baghurst, P., \& Sawyer, M. (2012). Resilience and its association with depression, emotional and behavioural problems, and mental health service utilisation among refugee adolescents living in South Australia. International Journal of Population Research, 485956, 1-9 .

Zatura, A. J., Hall, J. D., \& Murray, K. E. (2008). Resilience: a new integrative approach to health and menthal health research. Health Psychology Review, 2(1), 41-64. 


\title{
Gorjana Vujović ${ }^{3}$ \\ Đorđe Petronić ${ }^{4}$ \\ Psychology departmant \\ Faculty of Philosophy \\ University of East Sarajevo \\ Istočno Sarajevo, Republika Srpska
}

\section{RESILIENCE AS A PREDICTOR OF SOCIALLY UNACCEPTABLE BEHAVIOR}

\begin{abstract}
The research problem has been conceptualized as an examination of the possibility to predict socially unacceptable behaviour by using resilience as a predictor. In this context, self-reported socially unacceptable behaviour has been examined, while the resilience has been analysed with regard to two aspects in which it can be conceptualized. The first one is Ego-resiliency which is defined as a personality trait, and it is related to adaption during the inhibition or expression of emotions, in an interdependent relation to the environment in which the person is. The second aspect is resilience defined through intrapersonal and interpersonal capacities of person which affect adaptation and tolerance to stress and negative life experiences. The research has been conducted by using convenience sample of 384 respondents of high school final-year students, from Republika Srpska $(\mathrm{BiH})$. The hierarchical regression analysis has been used, while the applied measurement instruments were the following: RSA Resilience Scale for Adults, Ego-resiliency scale, the scale of anti-social behaviour, as well as scales that measure dimensions of Aggressiveness and Conscientiousness from the Big five +2 instrument. The results of the hierarchical regression analysis showed resilience as a statistically significant predictor of socially unacceptable behaviour $(R$ $\left.=.40, R^{2}=.160, F(4,318)=15.09, p=.000\right)$. When it comes to individual predictors, Conscientiousness $(\beta=-.24, p=.000)$ and Aggressiveness $(\beta=.19, p=.000)$ are still dominant (after the two measures of resilience are added to the model in the second step), which is followed by the resilience (RSA; $\beta=-.16, p=.012)$. It is important to note that Ego-resiliency has not been identified as a statistically significant predictor of socially unacceptable behavior $(\beta=.06, p=.342)$. The results contribute to the understanding of antisocial behavior causes and consequently contribute to its prevention.
\end{abstract}

Keywords: resilience, Ego-resiliency, socially unacceptable behaviour

Primljeno: 27.04.2020.

Primljena korekcija: 07.09.2020.

Prihvaćeno za objavljivanje:17.09.2020.

\footnotetext{
${ }^{3}$ gorjana.vujovic@ffuis.edu.ba

${ }^{4}$ djordje.petronic@ffuis.edu.ba
} 